\title{
Rapid diagnostic PCR method for identification of the genera Sarcocornia and Salicornia
}

\author{
Método de PCR de diagnóstico rápido para identificación de los géneros \\ Sarcocornia y Salicornia
}

Roberto Contreras $^{1 *}$, Bernardo Sepúlveda $^{1}$, Fernanda Aguayo $^{1}$, Vincenzo Porcile ${ }^{1}$

\begin{abstract}
Plants that belong to different genera sometimes may present close morphological similarity and cannot be distinguished phenotypically by non-specialists. The aim of this study was to develop a simple diagnostic PCR for the identification of plants of Sarcocornia and Salicornia and to test this new procedure to identify 82 samples of Sarcocornia neii from coastal and valleys of the Atacama region of Chile. Six primer pairs were designed from ETS sequences of the genera Sarcocornia and Salicornia and evaluated for the identification of both genera. Primers with a mismatch in the 3' nucleotide indicate the site of the SNP. Four primer pairs (SALI2F-2R, SALI3F-4R, SARCO1F-1R and SARCO3F-3R) were selected to develop an efficient and simple diagnostic PCR for the identification of Sarcocornia and Salicornia. The results show that with this method is possible to identify Sarcocornia and Salicornia. This method may be useful as an approach for genetic traceability of conserved products (sea asparagus). This work provides an applicable and efficient method using only DNA, PCR and electrophoresis.
\end{abstract}

Key words: Sarcocornia, PCR, allele-specific primer, SNP.

\section{RESUMEN}

Las plantas que pertenecen a diferentes géneros, a veces, pueden presentar fuertes similitudes morfológicas y pueden no ser identificadas fenotípicamente por no especialistas. El objetivo de este trabajo fue desarrollar una PCR diagnóstico para la identificación de plantas de los géneros Sarcocornia y Salicornia y probar este nuevo procedimiento para identificar 82 muestras de Sarcocornia neii distribuidas en la costa y valles de la región de Atacama. Se diseñó seis parejas de cebadores a partir de secuencias ETS de los géneros Sarcocornia y Salicornia, y se evaluó la identificación de cada género. Los cebadores contienen un desajuste en el nucleótido 3' que corresponde al sitio del SNP. Se seleccionaron cuatro pares de cebadores (SALI2F-2R, SALI3F-4R, SARCO1F-1R y SARCO3F-3R) para desarrollar una PCR de diagnóstico eficiente y simple para la identificación de los géneros Sarcocornia y Salicornia. El resultado muestra que con este método se puede identificar los géneros Sarcocornia y Salicornia. Adicionalmente, este método puede ser útil como propuesta para la trazabilidad genética de productos conservados (espárragos de mar). Este trabajo proporciona una aplicación eficiente, utilizando sólo ADN, PCR y electroforesis.

Palabras clave: Sarcocornia, PCR, primer específicos de alelos, SNP.

\section{Introduction}

The genus Sarcocornia was established by Scott (1978), who separated it from Salicornia L. and Arthrocnemum Moq on the basis of morphological characteristics. Currently, Sarcocornia includes about 28 species of perennial succulent halophytes distributed worldwide (Steffen et al., 2015). Since Scott's publication, the validity of the distinction of these genera has been questioned. Taxonomic studies of Salicornia in South America initially indicated the presence of this genus in Chile (Gunckel, 1978) and Peru (Gutte and Muller, 1985) as well as other countries; however, Scott (1978) concluded that these plants belong to the genus Sarcocornia. Scott (1978) defined two species in the South American continent as Sarcocornia fruticosa and Sarcocornia pulvinata. Later, Alonso and Crespo (2008) redefined

1 Centro de Investigación para el Desarrollo Sustentable de Atacama (CRIDESAT), Universidad de Atacama. Copiapó, Chile.

* Correspondig author: roberto.contreras@uda.cl

Fecha de Recepción: 23 agosto, 2017.

Fecha de Aceptación: 05 junio, 2018. 
Sarcocornia individuals in the American continent, recognizing four new species and confirming one of those established by Scott (1978), named S. neei, S. ambigua, S. andina, S. magellanica and S. pulvinata.

Sarcocornia is described as a pioneer plant in marine environments, and is characterized by extreme salt tolerance (Davy et al., 2006). In the coastal Pacific, halophilic communities of Sarcocornia grow in saline coastal marshes of Chile, coastal regions of the south Pacific slope of Peru (San Martín et al., 2006; Montesinos-Tubée, 2012), and saltmarshes of the Andes of northern Chile (Faúndez and Macaya, 1997). Due to their high salt tolerance, both Salicornia and Sarcocornia possess significant potential as a production model for arid and saline environments (Katschnig et al., 2013); they have by high nutritional value and high biomass yield in field conditions (Ventura and Sagi, 2013). Salicornia is presently cultivated commercially for human consumption in Israel; it has been introduced to the European market as a vegetable with leafless shoots resembling green asparagus, and is in great demand in gourmet kitchens due to its high mineral and antioxidant content (Ventura et al., 2011; Lu et al., 2010). In aquaculture production, a diet of Salicornia bigelovii flour supplied to juveniles of the blue shrimp L. stylirostris in intensive production systems has produced positive results in terms of growth and survival, and offers a low-cost alternative to more expensive fish- and corn-based flour (Acosta-Ruiz et al., 2011).

Salicornia and Sarcocornia show marked morphological similarity; they are distinguished phenotypically by inflorescence characteristics and life form (Steffen et al., 2015). However, according to studies on the basis of morphological characteristics by Judd and Ferguson (1999) including flower arrangement and growth habit, these features alone are insufficient to distinguish the genera confidently. Molecular markers could serve as a modern approach for identification of these plants.

Many types of molecular techniques have been used to identify plants of a wide range of varieties, species and genera, including RFLP, AFLP, RAPD and ASP-PCR (allele-specific primer PCR). Among these, allele-specific primer PCR by agarose gel electrophoresis is recognized as an efficient approach for cultivar identification (Soleimani et al., 2003). Likewise, diagnostic PCR using specific primers offers a cost-effective alternative for molecular identification of specific plant taxa. SNPs (single nucleotide polymorphisms) can be detected using allele-specific PCR primers designed in such a manner that the 3 ' nucleotide of a primer corresponds to the site of the SNP (Ugozzoli and Wallace, 1991). This technique allows preferential amplification of one allele relative to another on account of the primers being complementary to the site of DNA (Ugozzoli \& Wallace 1991). Using this technique, SNPs from ETS sequences of Salicornia and Sarcocornia (Steffen et al., 2015) could potentially be applied to discriminate between genera.

The goal of this study was to design allele-specific primers for amplification of short fragments from ETS sequences of Sarcocornia and Salicornia, and to evaluate an efficient diagnostic PCR to discriminate Salicornia and Sarcocornia using samples from the Atacama, Coquimbo and Los Lagos regions of Chile and Salicornia control samples.

\section{Materials and Methods}

\section{Plant Materials}

Eighty two Sarcocornia neii plants from the Atacama Region and seven S. neii plants from the Coquimbo Region were sampled during 2016. Plants were selected randomly and located by GPS as shown in Table 1. Two DNA samples of Salicornia europaea, supplied by Dr. Dirk Albach (Institut für Biologie und Umweltwissenschaften, Carl von OssietzkyUniversität, Germany), were used as positive Salicornia controls. Salicornia 1 control (ecotype 1) and Salicornia 2 control (ecotype 2) were collected by Dr. Albach near mudflats and low salt marshes in Spiekeroog Island (Germany), respectively. Two DNA samples of Sarcocornia perennis from Spain and two DNA samples of Sarcocornia neii from

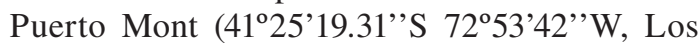
Lagos region) were used as a positive Sarcocornia control. Sarcocornia plants used as DNA controls were identified morphologically according to Scott's approach. All samples were processed and analyzed in the CRIDESAT Research Center, University of Atacama.

\section{Plant DNA Extraction}

Genomic DNA from eighty nine plants was extracted by a modified CTAB method following the procedure described by Doyle and Doyle (1987). Five grams of stem material were placed in sterile mortars 
Table 1: Origin, location and samples collected in the Atacama and Coquimbo regions of Chile.

\begin{tabular}{|c|c|c|c|c|c|c|c|}
\hline Samples & Latitude ( $\left.{ }^{\circ} \mathrm{S}\right)$ & Longitude $\left({ }^{\circ} \mathrm{W}\right)$ & Altitude $(\mathrm{m})$ & Samples & Latitude ( $\left.{ }^{\circ} \mathrm{S}\right)$ & Longitude $\left({ }^{\circ} \mathrm{W}\right)$ & Altitude (m) \\
\hline $\mathrm{RCOP} 02$ & $27^{\circ} 19^{\prime} 22.9^{\prime \prime} \mathrm{S}$ & $70^{\circ} 50^{\prime} 39.2 ” \mathrm{~W}$ & 60 & CLTO54 & $27^{\circ} 49^{\prime} 49.2^{\prime \prime} \mathrm{S}$ & $71^{\circ} 05^{\prime} 12.3^{\prime \prime} \mathrm{W}$ & 4 \\
\hline $\mathrm{RCOP} 03$ & $27^{\circ} 19^{\prime} 22.8^{\prime \prime} \mathrm{S}$ & $70^{\circ} 50^{\prime} 38.9^{\prime \prime} \mathrm{W}$ & 61 & CLTO55 & $27^{\circ} 49^{\prime} 49.0^{\prime \prime} \mathrm{S}$ & $71^{\circ} 05^{\prime} 12.4^{\prime \prime} \mathrm{W}$ & 4 \\
\hline RCOP04 & $27^{\circ} 19^{\prime} 23.0^{\prime \prime} \mathrm{S}$ & $70^{\circ} 50^{\prime} 39.3^{\prime \prime} \mathrm{W}$ & 56 & CLTO56 & $27^{\circ} 49^{\prime} 48.7^{\prime \prime} \mathrm{S}$ & $71^{\circ} 05^{\prime} 11.6 ” \mathrm{~W}$ & 3 \\
\hline RCOP05 & $27^{\circ} 19^{\prime} 23.3^{\prime \prime} \mathrm{S}$ & $70^{\circ} 50^{\prime} 39.8^{\prime \prime} \mathrm{W}$ & 58 & CLTO57 & $27^{\circ} 49^{\prime} 48.7^{\prime \prime S}$ & $71^{\circ} 05^{\prime} 11.1^{\prime \prime} \mathrm{W}$ & 2 \\
\hline PVCO08 & $27^{\circ} 12^{\prime} 31.1^{\prime \prime} \mathrm{S}$ & $70^{\circ} 57^{\prime} 05.9$ 'W & 1 & CLTO58 & $27^{\circ} 49^{\prime} 48.4^{\prime \prime} \mathrm{S}$ & $71^{\circ} 05^{\prime} 10.9^{\prime \prime} \mathrm{W}$ & 4 \\
\hline PVCO09 & $27^{\circ} 12^{\prime} 31.6^{\prime \prime} \mathrm{S}$ & $70^{\circ} 57^{\prime} 05.3^{\prime \prime} \mathrm{W}$ & 1 & CLTO59 & $27^{\circ} 49^{\prime} 48.2^{\prime \prime} \mathrm{S}$ & $71^{\circ} 05^{\prime} 10.4^{\prime \prime} \mathrm{W}$ & 2 \\
\hline PVCO10 & $27^{\circ} 12^{\prime} 32.5^{\prime \prime} \mathrm{S}$ & $70^{\circ} 57^{\prime} 03.5^{\prime \prime} \mathrm{W}$ & 1 & CLTO60 & $27^{\circ} 49^{\prime} 48.4^{\prime \prime S}$ & $71^{\circ} 05^{\prime} 10.2^{\prime \prime} \mathrm{W}$ & 1 \\
\hline PVCO11 & $27^{\circ} 12^{\prime} 33.4^{\prime \prime} \mathrm{S}$ & $70^{\circ} 57^{\prime} 02.2^{\prime \prime} \mathrm{W}$ & 1 & CLTO61 & $27^{\circ} 49^{\prime} 47.5^{\prime \prime} \mathrm{S}$ & $71^{\circ} 05^{\prime} 09.8^{\prime \prime} \mathrm{W}$ & 3 \\
\hline PVCO12 & $27^{\circ} 12^{\prime} 35.3^{\prime \prime} \mathrm{S}$ & $70^{\circ} 57^{\prime} 01.3 ” \mathrm{~W}$ & 1 & CLTO62 & $27^{\circ} 49^{\prime} 47.4^{\prime \prime} \mathrm{S}$ & $71^{\circ} 05^{\prime} 09.6^{\prime \prime} \mathrm{W}$ & 2 \\
\hline DECO13 & $27^{\circ} 16^{\prime} 39.6^{\prime \prime} \mathrm{S}$ & $70^{\circ} 56^{\prime} 32.6^{\prime \prime} \mathrm{W}$ & 0 & CLTO63 & $27^{\circ} 49^{\prime} 54.6^{\prime \prime} \mathrm{S}$ & $71^{\circ} 05^{\prime} 11.5^{\prime \prime} \mathrm{W}$ & 7 \\
\hline DECO14 & $27^{\circ} 16^{\prime} 39.9^{\prime \prime} \mathrm{S}$ & $70^{\circ} 56^{\prime} 32.4^{\prime \prime} \mathrm{W}$ & 0 & CLTO64 & $27^{\circ} 49^{\prime} 53.8^{\prime \prime} \mathrm{S}$ & $71^{\circ} 05^{\prime} 11.8^{\prime \prime} \mathrm{W}$ & 4 \\
\hline DECO15 & $27^{\circ} 16^{\prime} 40.1^{\prime \prime} \mathrm{S}$ & $70^{\circ} 56^{\prime} 32.2^{\prime \prime} \mathrm{W}$ & 0 & CABJ65 & $28^{\circ} 05^{\prime} 16.1^{\prime \prime S}$ & $71^{\circ} 08^{\prime} 27.3^{\prime \prime} \mathrm{W}$ & 6 \\
\hline DECO16 & $27^{\circ} 16^{\prime} 40.3^{\prime \prime} \mathrm{S}$ & $70^{\circ} 56^{\prime} 32.0^{\prime \prime} \mathrm{W}$ & 0 & CABJ66 & $28^{\circ} 05^{\prime} 15.9^{\prime \prime S}$ & $71^{\circ} 08^{\prime} 27.7^{\prime \prime} \mathrm{W}$ & 4 \\
\hline DECO17 & $27^{\circ} 16^{\prime} 40.6^{\prime \prime} \mathrm{S}$ & $70^{\circ} 56^{\prime} 31.6 ” \mathrm{~W}$ & 0 & CABJ67 & $28^{\circ} 05^{\prime} 16.0^{\prime \prime} \mathrm{S}$ & $71^{\circ} 08^{\prime} 27.9^{\prime \prime} \mathrm{W}$ & 3 \\
\hline DECO18 & $27^{\circ} 16^{\prime} 41.1^{\prime \prime} \mathrm{S}$ & $70^{\circ} 56^{\prime} 31.1^{\prime \prime} \mathrm{W}$ & 0 & CABJ68 & $28^{\circ} 05^{\prime} 16.4^{\prime \prime S}$ & $71^{\circ} 08^{\prime} 28.4^{\prime \prime} \mathrm{W}$ & 4 \\
\hline DECO19 & $27^{\circ} 16^{\prime} 41.5^{\prime \prime} \mathrm{S}$ & $70^{\circ} 56^{\prime} 30.9^{\prime \prime} \mathrm{W}$ & 0 & CABJ69 & $28^{\circ} 05^{\prime} 16.7^{\prime \prime S}$ & $71^{\circ} 08^{\prime} 29.8^{\prime \prime} \mathrm{W}$ & 5 \\
\hline DECO20 & $27^{\circ} 16^{\prime} 42.1^{\prime \prime} \mathrm{S}$ & $70^{\circ} 56^{\prime} 30.7^{\prime \prime} \mathrm{W}$ & 0 & CABJ70 & $28^{\circ} 05^{\prime} 16.7^{\prime \prime S}$ & $71^{\circ} 08^{\prime} 30.4^{\prime \prime} \mathrm{W}$ & 5 \\
\hline DECO21 & $27^{\circ} 16^{\prime} 42.7^{\prime \prime} \mathrm{S}$ & $70^{\circ} 56^{\prime} 30.2^{\prime \prime} \mathrm{W}$ & 0 & CABJ71 & $28^{\circ} 05^{\prime} 16.7^{\prime \prime S}$ & $71^{\circ} 08^{\prime} 31.9^{\prime \prime} \mathrm{W}$ & 3 \\
\hline DECO22 & $27^{\circ} 16^{\prime} 43.4^{\prime \prime} \mathrm{S}$ & $70^{\circ} 56^{\prime} 29.0^{\prime \prime} \mathrm{W}$ & 0 & CABJ72 & $28^{\circ} 05^{\prime} 15.9^{\prime \prime} \mathrm{S}$ & $71^{\circ} 08^{\prime} 32.8^{\prime \prime} \mathrm{W}$ & 3 \\
\hline DECO23 & $27^{\circ} 16^{\prime} 57.4^{\prime \prime} \mathrm{S}$ & $70^{\circ} 56^{\prime} 16.4 ” \mathrm{~W}$ & 0 & CABJ73 & $28^{\circ} 05^{\prime} 15.2^{\prime \prime S}$ & $71^{\circ} 08^{\prime} 32.8^{\prime \prime} \mathrm{W}$ & 5 \\
\hline DECO24 & $27^{\circ} 16^{\prime} 57.4^{\prime \prime} \mathrm{S}$ & $70^{\circ} 56^{\prime} 16.5 ” \mathrm{~W}$ & 0 & CABJ74 & $28^{\circ} 05^{\prime} 14.2^{\prime \prime S}$ & $71^{\circ} 08^{\prime} 32.8^{\prime \prime} \mathrm{W}$ & 7 \\
\hline $\mathrm{DECO} 25$ & $27^{\circ} 17^{\prime} 22.6^{\prime \prime S}$ & $70^{\circ} 56^{\prime} 02.8^{\prime \prime} \mathrm{W}$ & 0 & CABJ75 & $28^{\circ} 05^{\prime} 13.4^{\prime \prime S}$ & $71^{\circ} 08^{\prime} 33.4^{\prime \prime} \mathrm{W}$ & 5 \\
\hline DECO26 & $27^{\circ} 17^{\prime} 22.7^{\prime \prime} \mathrm{S}$ & $70^{\circ} 56^{\prime} 02.9^{\prime \prime} \mathrm{W}$ & 0 & CABJ76 & $28^{\circ} 05^{\prime} 13.3^{\prime \prime S}$ & $71^{\circ} 08^{\prime} 33.6^{\prime \prime} \mathrm{W}$ & 2 \\
\hline DECO27 & $27^{\circ} 17^{\prime} 29.0^{\prime \prime} \mathrm{S}$ & $70^{\circ} 56^{\prime} 00.0^{\prime \prime} \mathrm{W}$ & 0 & CABJ77 & $28^{\circ} 05^{\prime} 12.4^{\prime \prime S}$ & $71^{\circ} 08^{\prime} 33.4^{\prime \prime} \mathrm{W}$ & 4 \\
\hline DECO28 & $27^{\circ} 17^{\prime} 29.2^{\prime \prime S}$ & $70^{\circ} 56^{\prime} 00.0^{\prime \prime} \mathrm{W}$ & 0 & CABJ78 & $28^{\circ} 05^{\prime} 12.1$ ”'S & $71^{\circ} 08^{\prime} 33.7^{\prime \prime} \mathrm{W}$ & 4 \\
\hline DECO29 & $27^{\circ} 17^{\prime} 38.0^{\prime \prime} \mathrm{S}$ & $70^{\circ} 55^{\prime} 56.2^{\prime \prime} \mathrm{W}$ & 0 & CABJ79 & $28^{\circ} 05^{\prime} 11.3^{\prime \prime S}$ & $71^{\circ} 08^{\prime} 34.0^{\prime \prime} \mathrm{W}$ & 3 \\
\hline DECO30 & $27^{\circ} 17^{\prime} 38.2^{\prime \prime} \mathrm{S}$ & $70^{\circ} 55^{\prime} 56.2^{\prime \prime} \mathrm{W}$ & 0 & РВTO81 & $27^{\circ} 54^{\prime} 01.8^{\prime \prime S}$ & $70^{\circ} 57^{\prime} 05.3^{\prime \prime} \mathrm{W}$ & 151 \\
\hline DECO31 & $27^{\circ} 17^{\prime} 55.2^{\prime \prime} \mathrm{S}$ & $70^{\circ} 55^{\prime} 48.8^{\prime \prime} \mathrm{W}$ & 0 & PBTO82 & $27^{\circ} 54^{\prime} 01.7$ 'S & $70^{\circ} 57^{\prime} 05.2^{\prime \prime} \mathrm{W}$ & 151 \\
\hline DECO32 & $27^{\circ} 17^{\prime} 55.3^{\prime \prime} \mathrm{S}$ & $70^{\circ} 55^{\prime} 49.0^{\prime \prime} \mathrm{W}$ & 0 & PBTO83 & $27^{\circ} 54^{\prime} 01.4^{\prime \prime S}$ & $70^{\circ} 56^{\prime} 55.6^{\prime \prime} \mathrm{W}$ & 154 \\
\hline DECO33 & $27^{\circ} 18^{\prime} 12.5^{\prime \prime} \mathrm{S}$ & $70^{\circ} 55^{\prime} 43.8^{\prime \prime} \mathrm{W}$ & 0 & PBTO84 & $27^{\circ} 54^{\prime} 01.8^{\prime \prime S}$ & $70^{\circ} 56^{\prime} 55.4^{\prime \prime} \mathrm{W}$ & 154 \\
\hline DECO34 & $27^{\circ} 18^{\prime} 12.7^{\prime \prime} \mathrm{S}$ & $70^{\circ} 55^{\prime} 43.8^{\prime \prime} \mathrm{W}$ & 0 & PBTO85 & $27^{\circ} 54^{\prime} 02.1^{\prime \prime S}$ & $70^{\circ} 56^{\prime} 54.8^{\prime \prime} \mathrm{W}$ & 153 \\
\hline DECO37 & $27^{\circ} 19^{\prime} 03.4^{\prime \prime} \mathrm{S}$ & $70^{\circ} 55^{\prime} 06.8^{\prime \prime} \mathrm{W}$ & 4 & РBTO86 & $27^{\circ} 54^{\prime} 02.2^{\prime \prime S}$ & $70^{\circ} 56^{\prime} 54.5^{\prime \prime} \mathrm{W}$ & 152 \\
\hline DECO38 & $27^{\circ} 19^{\prime} 03.5^{\prime \prime} \mathrm{S}$ & $70^{\circ} 55^{\prime} 07.0^{\prime \prime} \mathrm{W}$ & 4 & PBTO87 & $27^{\circ} 54^{\prime} 02.2^{\prime \prime} \mathrm{S}$ & $70^{\circ} 56^{\prime} 54.6^{\prime \prime} \mathrm{W}$ & 152 \\
\hline DECO39 & $27^{\circ} 19^{\prime} 03.7^{\prime \prime S}$ & $70^{\circ} 55^{\prime} 07.1^{\prime \prime} \mathrm{W}$ & 5 & VAHS88 & $28^{\circ} 27^{\prime} 55.0^{\prime \prime} \mathrm{S}$ & $71^{\circ} 12^{\prime} 23.8^{\prime \prime} \mathrm{W}$ & 8 \\
\hline DECO43 & $27^{\circ} 19^{\prime} 15.8^{\prime \prime} \mathrm{S}$ & $70^{\circ} 55^{\prime} 04.0^{\prime \prime} \mathrm{W}$ & 8 & VAHS89 & $28^{\circ} 27^{\prime} 54.9^{\prime \prime S}$ & $71^{\circ} 12^{\prime} 23.8^{\prime \prime} \mathrm{W}$ & 8 \\
\hline DECO44 & $27^{\circ} 19^{\prime} 15.7^{\prime \prime} \mathrm{S}$ & $70^{\circ} 55^{\prime} 04.0^{\prime \prime} \mathrm{W}$ & 7 & VAHS90 & $28^{\circ} 27^{\prime} 54.8^{\prime \prime S}$ & $71^{\circ} 12^{\prime} 23.4^{\prime \prime} \mathrm{W}$ & 9 \\
\hline DECO45 & $27^{\circ} 19^{\prime} 16.0^{\prime \prime} \mathrm{S}$ & $70^{\circ} 55^{\prime} 04.1^{\prime \prime} \mathrm{W}$ & 6 & VAHS91 & $28^{\circ} 27^{\prime} 54.9^{\prime \prime S}$ & $71^{\circ} 12^{\prime} 23.0^{\prime \prime} \mathrm{W}$ & 10 \\
\hline CLTO46 & $27^{\circ} 49^{\prime} 50.5^{\prime \prime} \mathrm{S}$ & $71^{\circ} 05^{\prime} 15.1^{\prime \prime} \mathrm{W}$ & 2 & VAHS92 & $28^{\circ} 27^{\prime} 55.1^{\prime \prime S}$ & $71^{\circ} 12^{\prime} 22.9^{\prime \prime} \mathrm{W}$ & 10 \\
\hline CLTO47 & $27^{\circ} 49^{\prime} 50.5^{\prime \prime} \mathrm{S}$ & $71^{\circ} 05^{\prime} 14.8^{\prime \prime} \mathrm{W}$ & 1 & LASE93 & $29^{\circ} 57^{\prime} 40.4^{\prime \prime S}$ & $71^{\circ} 19^{\prime} 19.4^{\prime \prime} \mathrm{W}$ & 3 \\
\hline CLTO48 & $27^{\circ} 49^{\prime} 50.5^{\prime \prime S}$ & $71^{\circ} 05^{\prime} 14.4^{\prime \prime} \mathrm{W}$ & 1 & LASE94 & $29^{\circ} 57^{\prime} 40.3^{\prime \prime S}$ & $71^{\circ} 19^{\prime} 18.8^{\prime \prime} \mathrm{W}$ & 3 \\
\hline CLTO49 & $27^{\circ} 49^{\prime} 50.3^{\prime \prime} \mathrm{S}$ & $71^{\circ} 05^{\prime} 14.0^{\prime \prime} \mathrm{W}$ & 2 & LASE95 & $29^{\circ} 57^{\prime} 40.5^{\prime \prime} \mathrm{S}$ & $71^{\circ} 19^{\prime} 21.7^{\prime \prime} \mathrm{W}$ & 4 \\
\hline CLTO50 & $27^{\circ} 49^{\prime} 50.3^{\prime \prime} \mathrm{S}$ & $71^{\circ} 05^{\prime} 13.6^{\prime \prime} \mathrm{W}$ & 3 & LASE96 & $29^{\circ} 57^{\prime} 40.3 ” S$ & $71^{\circ} 19^{\prime} 22.9^{\prime \prime} \mathrm{W}$ & 4 \\
\hline CLTO51 & $27^{\circ} 49^{\prime} 50.3^{\prime \prime} \mathrm{S}$ & $71^{\circ} 05^{\prime} 13.2^{\prime \prime} \mathrm{W}$ & 2 & LASE97 & $29^{\circ} 57^{\prime} 39.9^{\prime \prime S}$ & $71^{\circ} 19^{\prime} 11.2^{\prime \prime} \mathrm{W}$ & 4 \\
\hline CLTO52 & $27^{\circ} 49^{\prime} 49.8^{\prime \prime} \mathrm{S}$ & $71^{\circ} 05^{\prime} 12.6^{\prime \prime} \mathrm{W}$ & 2 & LASE98 & $29^{\circ} 57^{\prime} 41.1$ ”S & $71^{\circ} 19^{\prime} 13.1^{\prime \prime} \mathrm{W}$ & 6 \\
\hline CLTO53 & $27^{\circ} 49^{\prime} 49.4^{\prime \prime} \mathrm{S}$ & $71^{\circ} 05^{\prime} 12.5^{\prime \prime} \mathrm{W}$ & 3 & LASE99 & $29^{\circ} 57^{\prime} 40.9^{\prime \prime S}$ & 71¹9'14.6”'W & 7 \\
\hline
\end{tabular}


at $-80^{\circ} \mathrm{C}$ for a period of $12 \mathrm{~h}$, and a fine powder produced. About $500 \mathrm{mg}$ of powder was placed in $2 \mathrm{~mL}$ tubes and mixed with $850 \mu \mathrm{L}$ of preheated $\left(65^{\circ} \mathrm{C}\right)$ extraction buffer $[100 \mathrm{mM}$ Tris- $\mathrm{HCl} \mathrm{pH}$ $8.0,1.4 \mathrm{M} \mathrm{NaCl}, 20 \mathrm{mM}$ EDTA, $2 \%$ (w/v) CTAB], supplemented with $0.7 \% \beta$-mercaptoethanol and $3 \%$ PVP-40. Samples were vortexed vigorously 10 $\mathrm{s}$ and incubated $1 \mathrm{~h}$ at $65^{\circ} \mathrm{C}$. Mixes were inverted three times during the incubation. The aqueous phase was recovered by centrifuging at $14000 \mathrm{rpm}$ for $10 \mathrm{~min}$. The recovered volume was mixed with an equal volume of chloroform-isoamyl alcohol (24:1). The mix was inverted gently over a period of $2 \mathrm{~min}$. Centrifugation at $14000 \mathrm{rpm}$ for $10 \mathrm{~min}$ was repeated. The upper phase was transferred to a new tube and treated with $5 \mu \mathrm{L}$ RNase A (100 $\mu \mathrm{g} / \mathrm{mL}$ ) at $37^{\circ} \mathrm{C}$ for $30 \mathrm{~min}$. The extraction was mixed with two-thirds volume isopropanol at $-20{ }^{\circ} \mathrm{C}$. The mix was inverted gently thirty times and incubated on ice for $40 \mathrm{~min}$. Centrifugation at $14000 \mathrm{rpm}$ for $10 \mathrm{~min}$ was repeated. The supernatant was discarded and a DNA pellet was obtained, to which a washing solution of $600 \mu \mathrm{L}$ of $70 \%$ ethanol and $10 \mathrm{mM}$ ammonium acetate was added; this was followed by centrifuging for 2 min at $14000 \mathrm{rpm}$. The wash was repeated twice. The washing solution was discarded and the DNA dried for $15 \mathrm{~min}$ at RT. To elute DNA, $20 \mu \mathrm{L}$ TE was added and incubated overnight at $4{ }^{\circ} \mathrm{C}$. Quality and concentration of total DNA were verified by Colibri Microvolume Spectrophotometer (Titertek Berthold, Germany) at 260, 280 and $230 \mathrm{~nm}$, and genomic DNA integrity checked on $0.7 \%$ agarose gels.

\section{Specific primer design}

Specific primers were designed using ETS (external transcribed spacer) sequences of ribosomal RNA from nine Salicornia species and eight Sarcocornia species previously obtained by Kadereit et al. (2007). The accession numbers of these 17 ETS sequences were obtained from GenBank (Figure 1). The sequences were aligned by MEGA 7.0 software and ClustalW as shown in Figure 1. Oligo ${ }^{\circledR}$ software was used to design three specific primer pairs each for Salicornia and Sarcocornia (Table 2) from conserved SNP. These six potentially genus-specific primer pairs were examined for their presence in other plant species available in GenBank (BlastN option, http:// www.ncbi.nlm.nih.gov/).

\section{PCR optimization}

DNA control samples were used as a template to investigate analytical sensitivity. Serial DNA concentrations were prepared for each PCR reaction at $1 \mathrm{ng}, 5 \mathrm{ng}, 10 \mathrm{ng}, 20 \mathrm{ng}$ and $30 \mathrm{ng}$ to establish the sensitivity limit of the PCR assay. PCR reactions were performed in $12 \mu \mathrm{L}$ final volume containing (1ng to $30 \mathrm{ng}$ ) DNA, $0.85 \mu \mathrm{L}$ each primer $(5 \mu \mathrm{M})$ and $6 \mu \mathrm{L}$ DreamTaq PCR Master Mix 2X (Thermo Scientific). Amplifications were carried out in Swift Max Pro (Esco) and MultiGene Optimax (Labnet) thermal cyclers with the following program: an initial step of 4 min at $94{ }^{\circ} \mathrm{C}, 35$ cycles of $30 \mathrm{~s}$ at $94{ }^{\circ} \mathrm{C}, 30$ s at $54{ }^{\circ} \mathrm{C}$ and $2 \mathrm{~min}$ at $72{ }^{\circ} \mathrm{C}$, followed by a final extension step of $7 \mathrm{~min}$ at $72{ }^{\circ} \mathrm{C}$. To determine the optimum annealing temperature (Ta), a gradient PCR was performed using DNA control samples from the Sarcocornia control (from Puerto Montt), and Salicornia 1 and 2 controls. The PCR mix and program were identical to those indicated above, but with optimized DNA concentration and a different Ta. The Ta were $50{ }^{\circ} \mathrm{C}, 50.7{ }^{\circ} \mathrm{C}, 51.5^{\circ} \mathrm{C}, 54^{\circ} \mathrm{C}, 57.2$ ${ }^{\circ} \mathrm{C}, 59.2{ }^{\circ} \mathrm{C}$ and $60^{\circ} \mathrm{C}$ in order to obtain the optimum temperature at which only the template DNA of Sarcocornia or Salicornia would be amplified. All PCR products were visualized on $1.5 \%$ TBE agarose gels.

\section{Multiplex PCR and allele-specific PCR}

To demonstrate that diagnostic PCR works well with specific Sarcocornia and Salicornia DNA primer pairs, a primer pair from plastid $t r n \mathrm{~L}$ (UAA) intron ( $110 \mathrm{pb}$ ) was used as a positive plant control in the same PCR reaction. The multiplex PCR to amplify plastid trnL (UAA) intron and the ETS region from Salicornia and Sarcocornia were performed under conditions similar to those used for PCR optimization, except for the primer concentrations: $1 \mu \mathrm{L}$ of each primer SALI or SARCO to $5 \mu \mathrm{M}$ and $0.7 \mu \mathrm{L}$ of each trnL primer to $5 \mu \mathrm{M}$ (F: 5'GGGCAATCCTGAGCCAA 3' R: 5' CCATTGAGTCTCTGCACCTATC 3'; Taberlet et al., 2006). The amplification of allele-specific diagnostic PCR was performed using 3 primers simultaneously in a reaction tube with genomic DNA from Sarcocornia and Salicornia controls. Diagnostic PCR reactions were performed in $16 \mu \mathrm{L}$ final volume containing 20 ng DNA, $0.55 \mu \mathrm{L}$ SARCO3F primer, $1.3 \mu \mathrm{L}$ SARCO1R, $0.55 \mu \mathrm{L}$ SARCO3R (all primers 


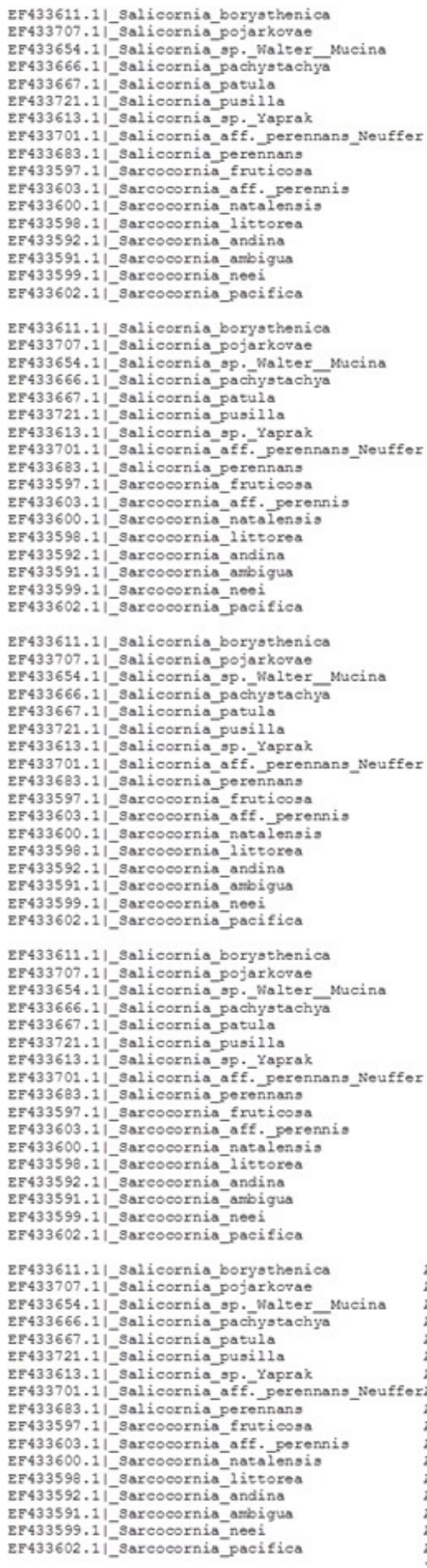

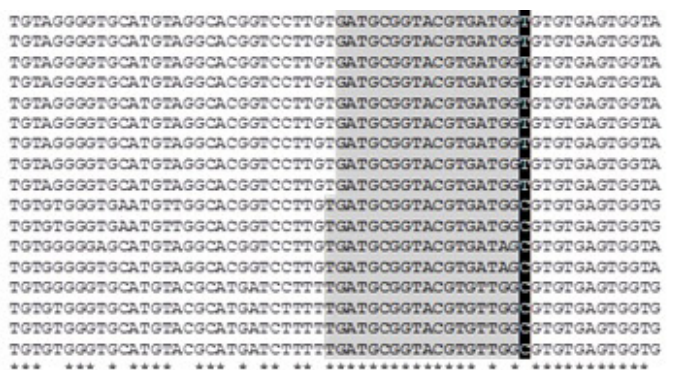

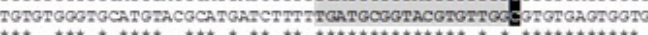

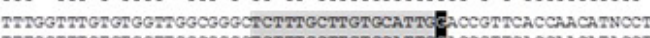

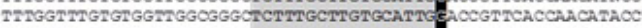

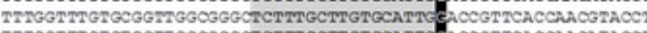

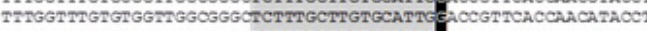

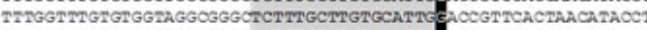

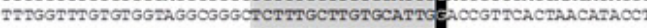

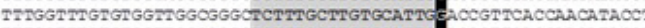

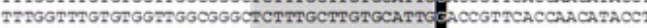

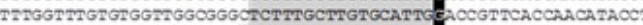

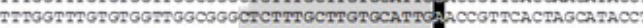

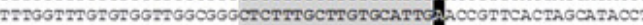

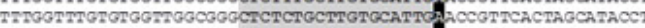

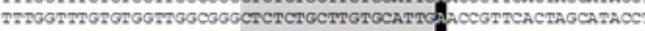

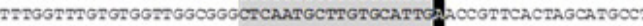

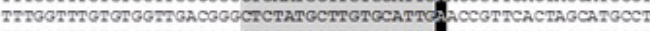

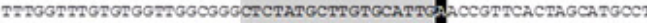

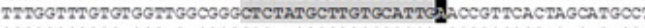

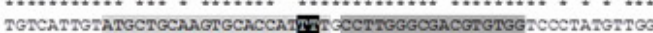

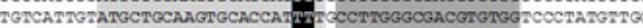

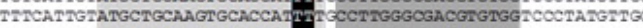

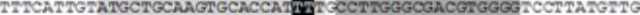

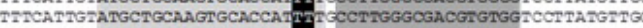

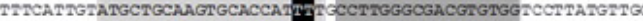

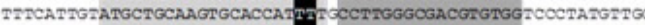

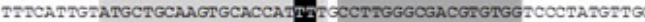

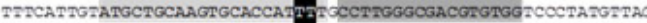

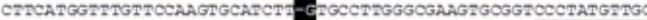

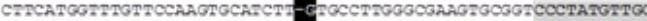

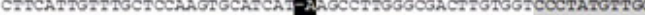

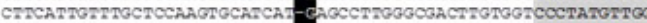

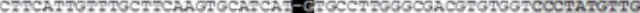

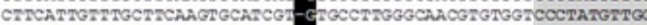

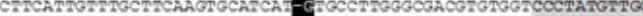

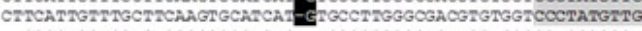

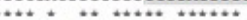

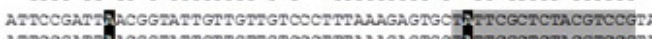

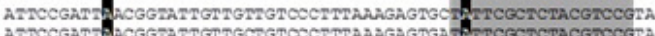

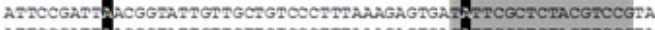

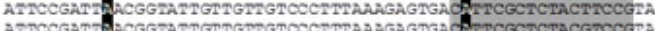

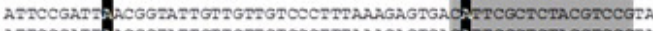

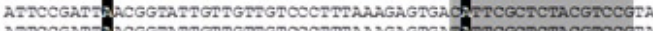

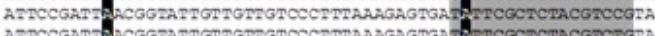

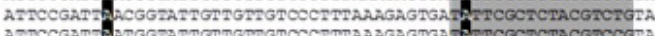

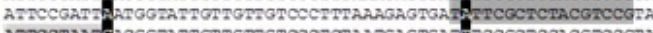

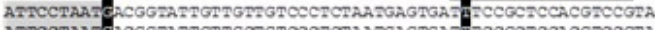

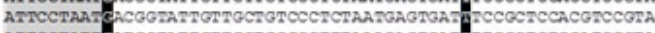

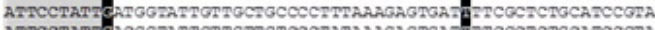

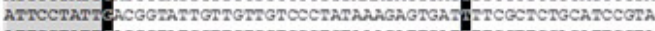

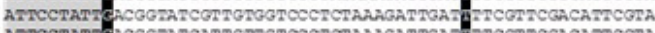

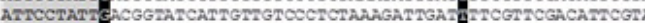

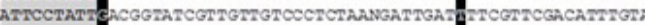

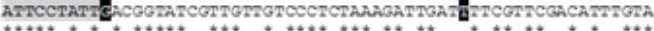
AMAGGRGGTCGRGCGGACCCNGMACTRGA CTCGTRATCCNCCTGR AMGGAGGTCGAGCGGACCCNGAHACTRGACTCGRTATCCROCTGH

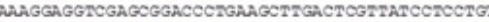
WHAGAGGICGAGCGGACCANGAAACTRGACTCSITATCCNCCTG AHGGAGGTCGAGCGGACCANGAACTRGACTCGTTATCCNCCTG ARAGGAGGICGAGGGGACCA IGAAACTIGACTOGITAICCNOCTGI

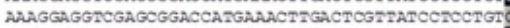
KADAGGAGGNCGAGCGGACCANGAAACTAGACTOSIRATCCACCIGT

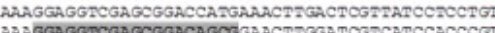
ANAGCAGGICGAGCGGACAGCDGAACTROGATCORCATCCACCCG ACAGGAGGTCGA CCGGACAGRGAAACTROGCTCGRAATCCACC-CD ACAGCAGGNCGAGCGGACA GNGAAACTROGCTCGRGATCCACC-CIAHAGGSGGNCGAGCGGACTGRGAAACTRGGCTCGTMATCCACCCT) ATAGCAGGICGAGCGGACTGKAAACTROGCTCONRATCCACCCTG ATAGGAGGTCGAGCGGACTGMAAACTRGGCTCGRTATCCACCCOS ATAGGAGGCGAGCGGCTGMAAACTRGGCTCGNRATCCACCCCGTCMAQGUNACAMCCACGAT

Figure 1: Position of specific primers in the ETS (external transcribed spacer) sequences of ribosomal RNA of nine Salicornia and eight Sarcocornia available in GenBank. Forward primer was colored in light grey and reverse primer in dark grey. Primers with SNP in position 3' were shown in white letters. 
Table 2: Sequences, temperature and SNP information of the primers designed.

\begin{tabular}{|c|c|c|c|c|c|c|}
\hline Primer name & Sequence (5'-3') & Target taxa & $\mathbf{T m}{ }^{\circ} \mathrm{C}$ & Length of base pair & SNP & Length of PCR product \\
\hline SALI1F & GATGCGGTACGTGATGGT & \multirow{2}{*}{ Salicornia sp. } & \multirow{2}{*}{54.3} & 18 & $\mathrm{~T} / \mathrm{C}$ & \multirow{2}{*}{138} \\
\hline SALI1R & CCACACGTCGCCCAAGG & & & 17 & -- & \\
\hline SALI2F & TCTTTGCTTGTGCATTGG & \multirow{2}{*}{ Salicornia sp. } & \multirow{2}{*}{51.9} & 18 & $\mathrm{G} / \mathrm{A}$ & \multirow{2}{*}{155} \\
\hline SALI2R & CGGACGTAGAGCGAATA & & & 17 & -- & \\
\hline SALI3F & ATGCTGCAAGTGCACCATTTT & \multirow{2}{*}{ Salicornia sp. } & \multirow{2}{*}{52.3} & 21 & T/G;T/- & \multirow{2}{*}{176} \\
\hline SALI4R & TCATGCTTGTTTTCACAAA & & & 19 & $\mathrm{~T} / \mathrm{C} ; \mathrm{T} / \mathrm{A}$ & \\
\hline SARCO1F & CTCTATGCTTGTGCATTGA & \multirow{2}{*}{ Sarcocornia sp. } & \multirow{2}{*}{52.5} & 19 & $\mathrm{~A} / \mathrm{G}$ & \multirow{2}{*}{221} \\
\hline SARCO1R & GTGCTTGTTTTCGCTTG & & & 17 & $\mathrm{C} / \mathrm{T} ; \mathrm{A} / \mathrm{T}$ & \\
\hline $\mathrm{SARCO} 2 \mathrm{~F}$ & TGATGCGGTACGTGTTGGC & \multirow{2}{*}{ Sarcocornia sp. } & \multirow{2}{*}{55.9} & 19 & $\mathrm{C} / \mathrm{T}$ & \multirow{2}{*}{232} \\
\hline SARCO2R & AACAGTCCGCTCGACCTCC & & & 19 & -- & \\
\hline SARCO3F & CCCTATGTTGGATTCCTATTG & \multirow{2}{*}{ Sarcocornia sp. } & \multirow{2}{*}{52.3} & 21 & $\mathrm{G} / \mathrm{A}$ & \multirow{2}{*}{243} \\
\hline SARCO3R & CATCCATCATCAGCGTAC $(*)$ & & & 18 & -- & \\
\hline
\end{tabular}

at $5 \mu \mathrm{M}$ ), and $8 \mu \mathrm{L}$ DreamTaq PCR Master Mix 2X (Thermo Scientific). Amplifications were carried out in Swift Max Pro (Esco) and MultiGene Optimax (Labnet) thermal cyclers, with the following program: an initial step of $4 \mathrm{~min}$ at $94^{\circ} \mathrm{C}, 35$ cycles of $30 \mathrm{~s}$ at $94{ }^{\circ} \mathrm{C}, 30 \mathrm{~s}$ at $52{ }^{\circ} \mathrm{C}$ and $2 \mathrm{~min}$ at $72{ }^{\circ} \mathrm{C}$, followed by a final extension step of $7 \mathrm{~min}$ at $72^{\circ} \mathrm{C}$. All PCR assays were repeated three times and PCR products visualized on $1.5 \%$ TBE agarose gels.

\section{Results and Discussion}

Various genetic techniques have been used to authenticate differences between different plant cultivars, varieties, species and genera. Recently the application of diverse molecular approaches has allowed the validation of plant species that previously, due to the difficulty in identifying plants based on morphological characteristics, were considered to be of questionable taxonomic status (Nybom et al., 2014). Systematic establishment of phylogenetic relationships in Salicornia and Sarcocornia using morphological markers is difficult due to the lack of or significant reduction of principal structures such as leaves and flowers (Kadereit et al., 2006). Morphological characteristics such as perennial habitat and similarity in flower size were the main basis of the argument to distinguish Sarcocornia from Salicornia (Scott, 1978). However, there are species such as Sarcocornia natalensis and Sarcocornia freitagii containing short-lived and herbaceous perennials. Therefore, the traditional characteristics used to identify these genera are currently insufficient (Steffen et al., 2015).
In this study, six primer pairs were designed to evaluate allele-specific amplifications from Salicornia and Sarcocornia. For this, the 3' end base of the forward or reverse primer was positioned strictly on the SNP. Prior to plant identification, two PCR optimization tests were performed using control DNA from each genus. The results of testing for PCR sensitivity showed good amplification of the expected fragments using samples containing between 1 and 20 ng per DNA/PCR reaction (Figure 2). Therefore, to ensure the effectiveness of the majority of PCR assays it was decided to employ a final volume of $15 \mathrm{ng}$ of DNA/14 $\mu \mathrm{L}$ PCR.

To evaluate the effect of annealing temperature (Ta), Salicornia and Sarcocornia control DNA was amplified using six primer pairs, using a Ta between $50^{\circ} \mathrm{C}$ and $60^{\circ} \mathrm{C}$. The results of the diagnostic PCR based on the SALI1F-SALI1R primer pair indicated the presence of a well-defined fragment of expected size and high intensity in Salicornia controls 1 and 2, whereas the same robust fragment was observed in the Sarcocornia control at all annealing temperatures (Figure 3). In contrast, correct amplifications were observed in both Salicornia controls with the SALI2F-SALI2R primer pair at almost all annealing temperatures, while the Sarcocornia control showed no amplification of fragments at different annealing temperatures. Secondary PCR products with SALI2F-SALI2R were observed in the Salicornia 1 control, however, these PCR products disappeared at Ta greater than $57.2^{\circ} \mathrm{C}$. The Salicornia controls of the SALI3F-SALI4R primer pair resulted in good amplification of fragments at all annealing temperatures, but not in the Sarcocornia control, which showed no amplification (Figure 3). 


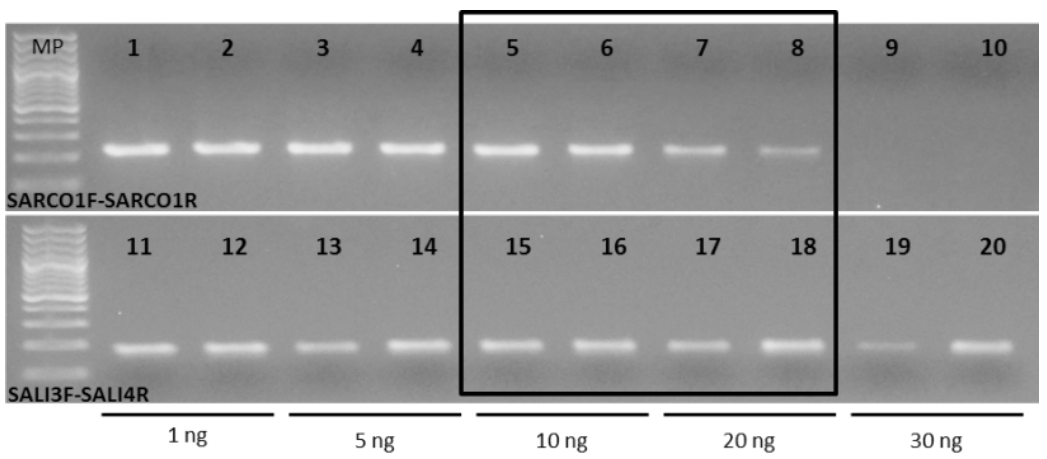

Figure 2: Agarose gel electrophoresis of PCR products obtained from the sensitivity test (1 ng to $30 \mathrm{ng}$ ) of primer pair SARCO1FSARCO1R and SALI3F-SALI4R. Lanes $1,3,5,7$ and $9=$ Sarcocornia control; $2,4,6,8$ and $10=$ DECO19; 11, 13, 15, 17 and $19=$ Salicornia 2 control; and 12, 14, 16, 18 and 20 = Salicornia 1 control. MP: 100 bp DNA ladder.

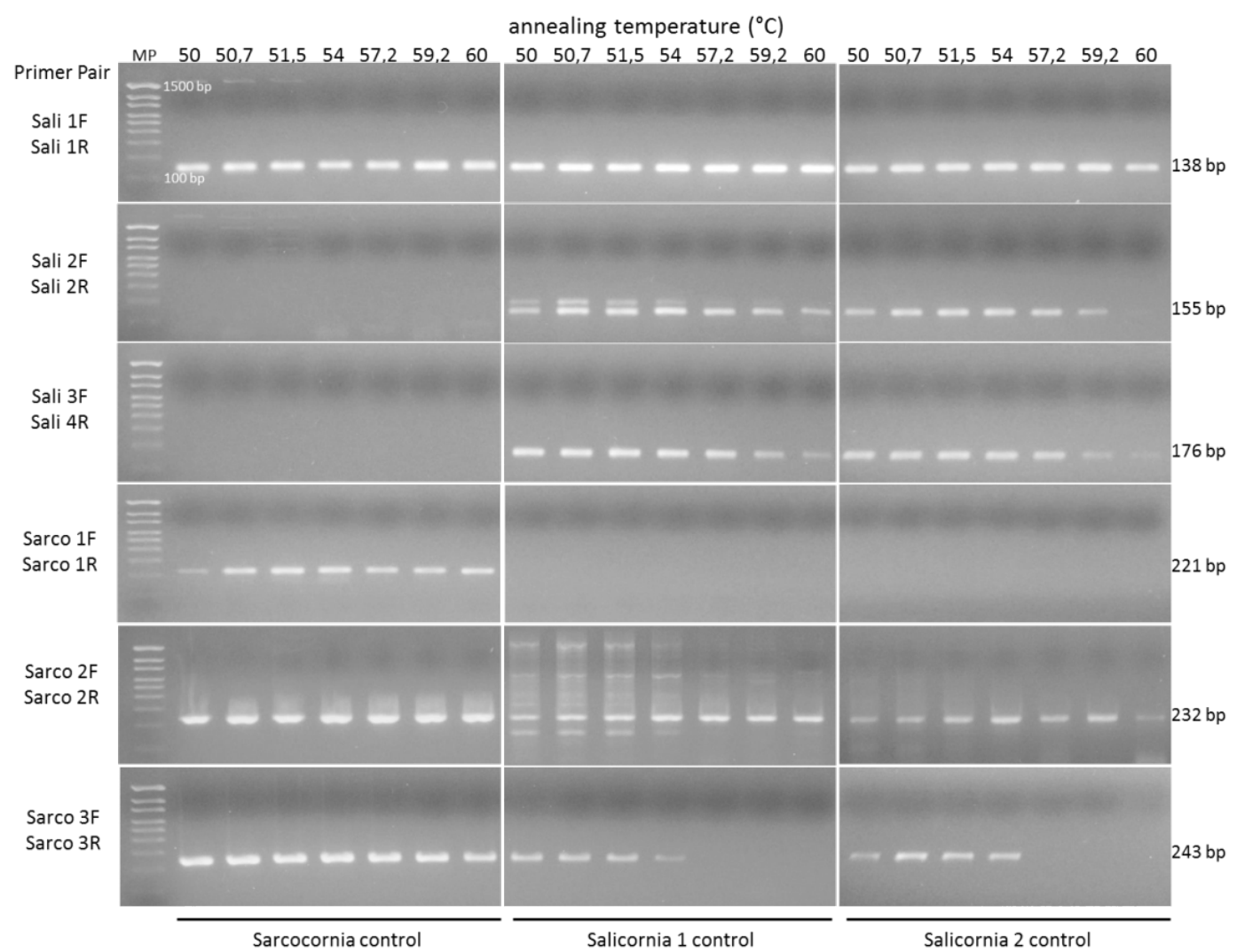

Figure 3: Electrophoresis of DNA amplified fragments obtained from annealing temperature (Ta) tests with Sarcocornia control (Sarcocornia Puerto Montt), Salicornia 1 control and Salicornia 2 control, using primer pair SALI1F-SALI1R (138 bp), SALI2F-SALI2R (155 bp), SALI3F-SALI4R (176 bp), SARCO1F-SARCO1R (221 bp), SARCO2F-SARCO2R (232 bp) and SARCO3F-SARCO3R (243 bp). MP: 100 bp DNA ladder. 
PCR based on the SARCO1-SARCO1F primer pair indicated the presence of a fragment of expected size in the Sarcocornia control, but no fragment was observed at any annealing temperature for Salicornia controls 1 and 2 (Figure 3). Amplification of fragments in both Salicornia and Sarcocornia controls was detected at different annealing temperatures using the SARCO2F-SARCO2R primer pair. Unlike previous primer pairs, the SARCO3F-SARCO3R primer pair showed good amplification of PCR fragments based on the Sarcocornia control at different annealing temperatures, although the Salicornia controls also showed fragment amplification at a temperature of 54 ${ }^{\circ} \mathrm{C}$; amplification was not observed at temperatures over $57.2^{\circ} \mathrm{C}$ (Figure 3 ).

Finally, two primer pairs (SALI1F-SALI1R and SARCO2F-SARCO2R) were discarded since they produced amplification in controls of both Sarcocornia and Salicornia. Each of these primer pairs had one SNP in the 3' end position of the forward primer. However, in the SARCO2FSARCO2R primer pair differences in amplification between Sarcocornia and Salicornia controls were observed at annealing temperatures of up to $68^{\circ} \mathrm{C}$, whereas no amplification differences were observed with the SALI1F -SALI1R primer pair at annealing temperatures of up to $72{ }^{\circ} \mathrm{C}$ (data not shown). The reason for this is that in most cases a single base pair change at the 3' end is not a sufficient basis for reliable discrimination (Kwok et al., 1994); in fact, this is the main reason that allele-specific primer techniques are not widely used. Otherwise, despite having one SNP in the 3' position on the forward primer, SALI2FSALI2R and SARCO3F-SARCO3R showed a good match in controls of the genera. However, large genus differences were demonstrated efficiently with SARCO1F-SARCO1R and SALI3F-SALI4R compared to other primer pairs. These primer pairs performed optimally because three consecutive SNPs from the 3' position were considered in the process of primer design. The high specificity of primer pairs SARCO1F-SARCO1R and SALI3F-SALI4R for genus detection is due to an increase in the number of SNP targets which were designed, such as forward and reverse primers.

To evaluate PCR amplification with a positive control fragment (trnL intron), primers selected to identify Sarcocornia and Salicornia were tested in a multiplex PCR assay including the $\operatorname{trn} L$ primer pair in the same reaction. The results indicated that the SARCO1F-SARCO1R and SARCO3F-SARCO3R primer pairs produced amplification of $\mathrm{PCR}$ products in Sarcocornia samples, whereas no amplification was observed in Salicornia controls. Likewise, the SALI2F-SALI2R and SALI3F-SALI4R primer pairs resulted in amplification in the Salicornia controls, but not in the Sarcocornia control. The trnL positive control primer pair was observed in all DNA samples mentioned above in a single band at $\sim 110 \mathrm{pb}$ (Figure $4 \mathrm{~A})$.

In another test, the diagnostic PCR by allelespecific primers (SARCO3F, SARCO1R and

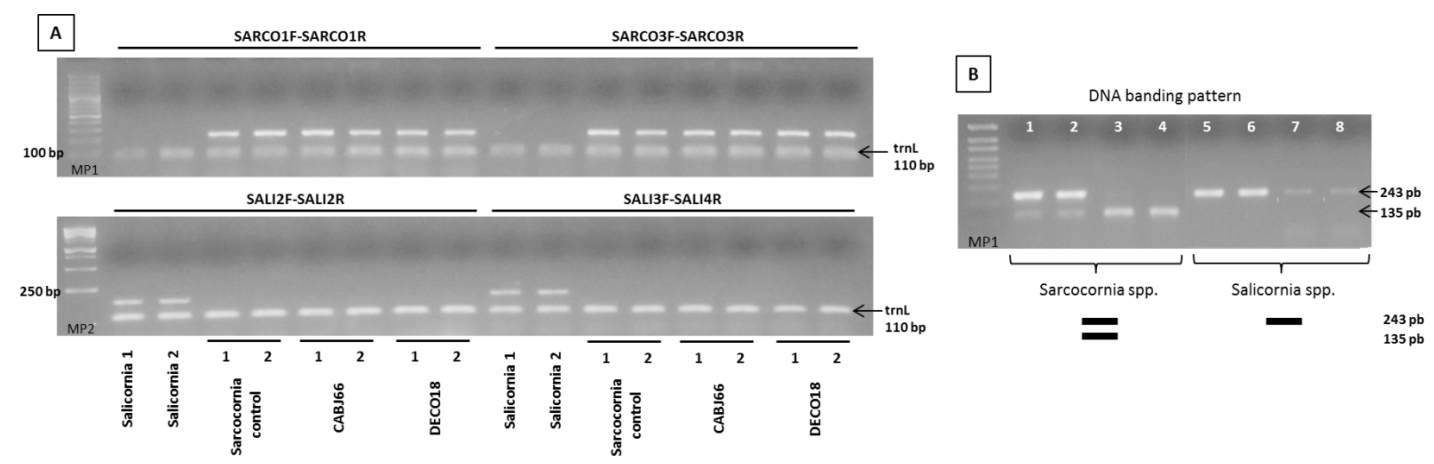

Figure 4: Example of diagnostic PCR with Salicornia and Sarcocornia. A) Electrophoresis of DNA amplified fragments obtained from Salicornia 1 control, Salicornia 2 control, Sarcocornia control (Puerto Montt), CABJ66 and DECO18 by means of multiplex PCR with a primer set of the $\operatorname{trn} L$ region and primer pairs SARCO1F-SARCO1R $\left(\mathrm{Ta}=54^{\circ} \mathrm{C}\right), \mathrm{SARCO} 3 \mathrm{~F}-\mathrm{SARCO} 3 \mathrm{R}\left(\mathrm{Ta}=57^{\circ} \mathrm{C}\right)$, SALI2F-SALI2R $\left(54^{\circ} \mathrm{C}\right)$ and SALI3F-SALI4R $\left(\mathrm{Ta}=54^{\circ} \mathrm{C}\right)$. B) Agarose gel electrophoresis of amplified fragments with two replicates from Sarcocornia controls (1, 2 = Sarcocornia of Puerto Montt; 3, 4 = Sarcocornia of Spain) and Salicornia controls (5, $6=$ Salicornia 2 control; 7, $8=$ Salicornia 1 control) and with three primers used for allele-specific PCR (SARCO3F, SARCO1R and SARCO3F). MP1: 100 bp DNA ladder and MP2: 1 kb DNA ladder. 
SARCO3F) were used to amplify Sarcocornia and Salicornia DNA in a simultaneous reaction. The result confirmed the presence of one DNA banding pattern for Sarcocornia and one DNA banding pattern for Salicornia: the former pattern with bands of 243 and $135 \mathrm{bp}$ and the latter with only one band of $243 \mathrm{bp}$ (Figure 4B). However, diagnostic PCR based on Spanish Sarcocornia DNA produced a weak $234 \mathrm{bp}$ band and a strong 135 bp band. The DNA of Sarcocornia showed a band of $135 \mathrm{bp}$, while this was not observed in Salicornia. In brief, using these specific primer pairs in a PCR reaction followed by agarose gel visualization offers a reliable method for identification of Sarcocornia and Salicornia; additionally, the detection and validation of SNPs from ETS sequences of these genera, described by Kadereit et al. 2007, was confirmed.

Using primer pairs appropriate for the identification of both genera, we tested 82 samples from the Atacama region, seven samples from the Coquimbo region, and two samples each from the Los Lagos region and from Spain. The results showed positive amplification in all plants (82) from the Atacama region using the SARCO1F$1 \mathrm{R}$ and SARCO3F-3R primer pairs, however two DNA samples (DECO23 and DECO32) did not show amplification, and one sample (DECO21) showed two PCR fragments using the SARCO3F-3R primer pair (Table 3). The DNA samples from the Coquimbo region, the Los Lagos region and Spain had positive amplification using the SARCO1F-1R and SARCO3F-3R primer pairs (Table 3). None of the DNA samples from any of the regions demonstrated amplification with the control primer SALI 2F-2R and SALI 3F-4R, although only the CABJ74 sample showed one PCR fragment similar to the expected size with SALI2F-2R. The results of the present study are consistent with the report of Alonso and Crespo (2008), indicating the predominance of Sarcocornia in Chile; this suggests that the approach is efficiently designed for the detection of plants of this genus. In addition, we believe that the method could theoretically be applied in other parts of the world, since the primer pairs were designed from representative Sarcocornia ETS sequences of three continents.

In a further step, this PCR diagnostic method was applied using Sarcocornia tissue from commercial products in which clear identification of genus (data not shown) was possible. This discrimination method could therefore potentially be useful for market quality control purposes, particularly given that distinctions on the basis of morphological characteristics (flower) and growth habit (area) are obviously not feasible in the case of final packaged products (sea asparagus). The potential for a molecular approach in this context is of particular interest considering the differences in nutritional and agronomic characteristics of the genera; Sarcocornia has a saltier taste than Salicornia, verified by an elevated EC (electrical conductivity) value in shoots immersed in seawater (Ventura et al., 2011), and although both possess high total lipid content relative to other plants using culture in seawater, the Salicornia ecotype exceeds Sarcocornia in terms of total fatty acids and omega-3 percentage. Furthermore, the annual Salicornia ecotype has higher yields than perennial Sarcocornia ecotypes (Ventura et al., 2011). In summary, a PCR-based genotyping method has been developed to discriminate between Salicornia and Sarcocornia using only DNA, PCR and electrophoresis.

\section{Conclusion}

In this study, a simple and reliable method through four specific-primers (SALI2F-2R, SALI3F4R, SARCO1F-1R and SARCO3F-3R), multiplex PCR and allele specific-primers has been developed to discriminate between Salicornia and Sarcocornia.

\section{Acknowledgments}

We sincerely thank Prof. César Benito (Departamento de Genética, Universidad Complutense de Madrid) for comments that greatly improved the paper and Niklas Buhk for assistance with Salicornia samples. 


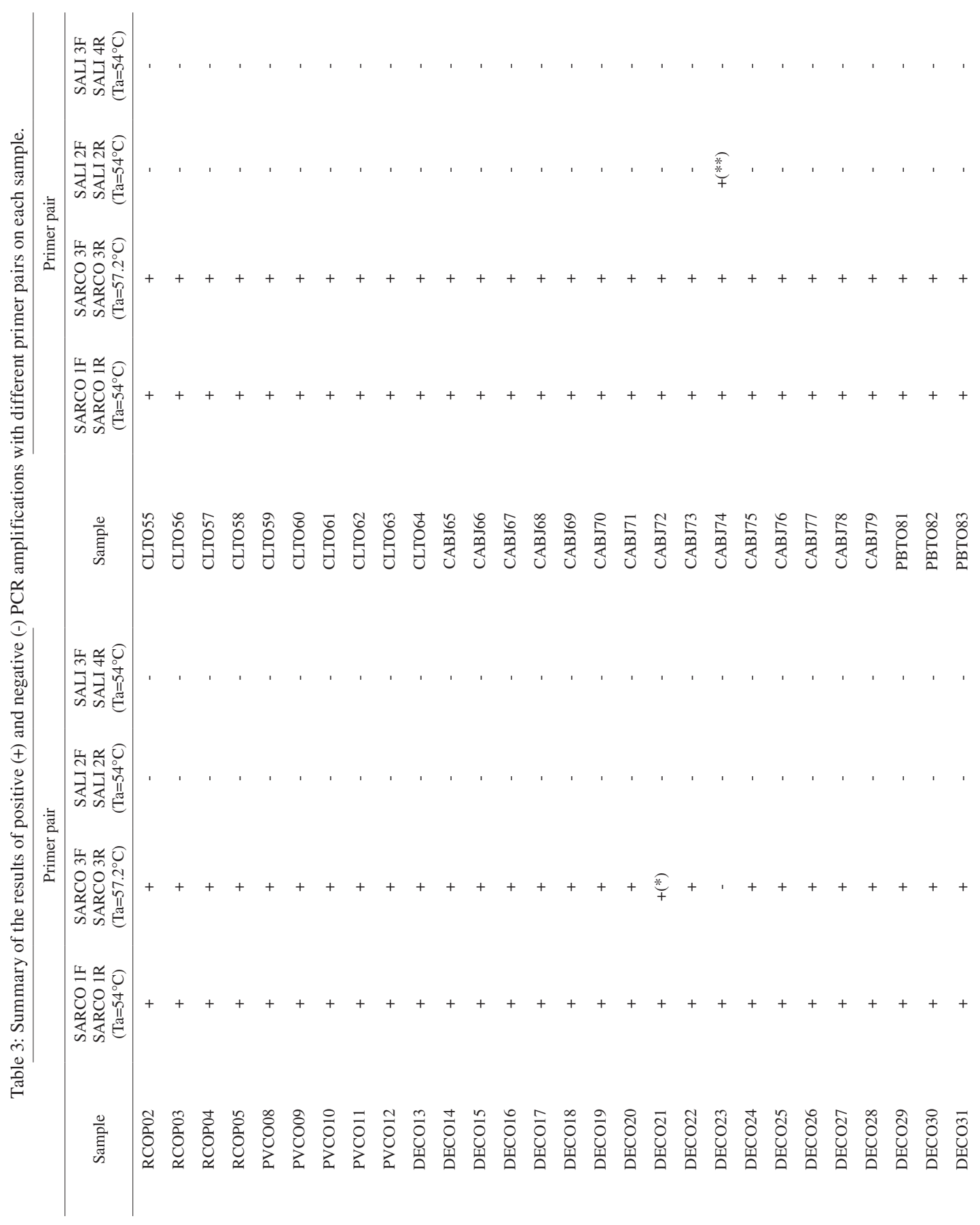




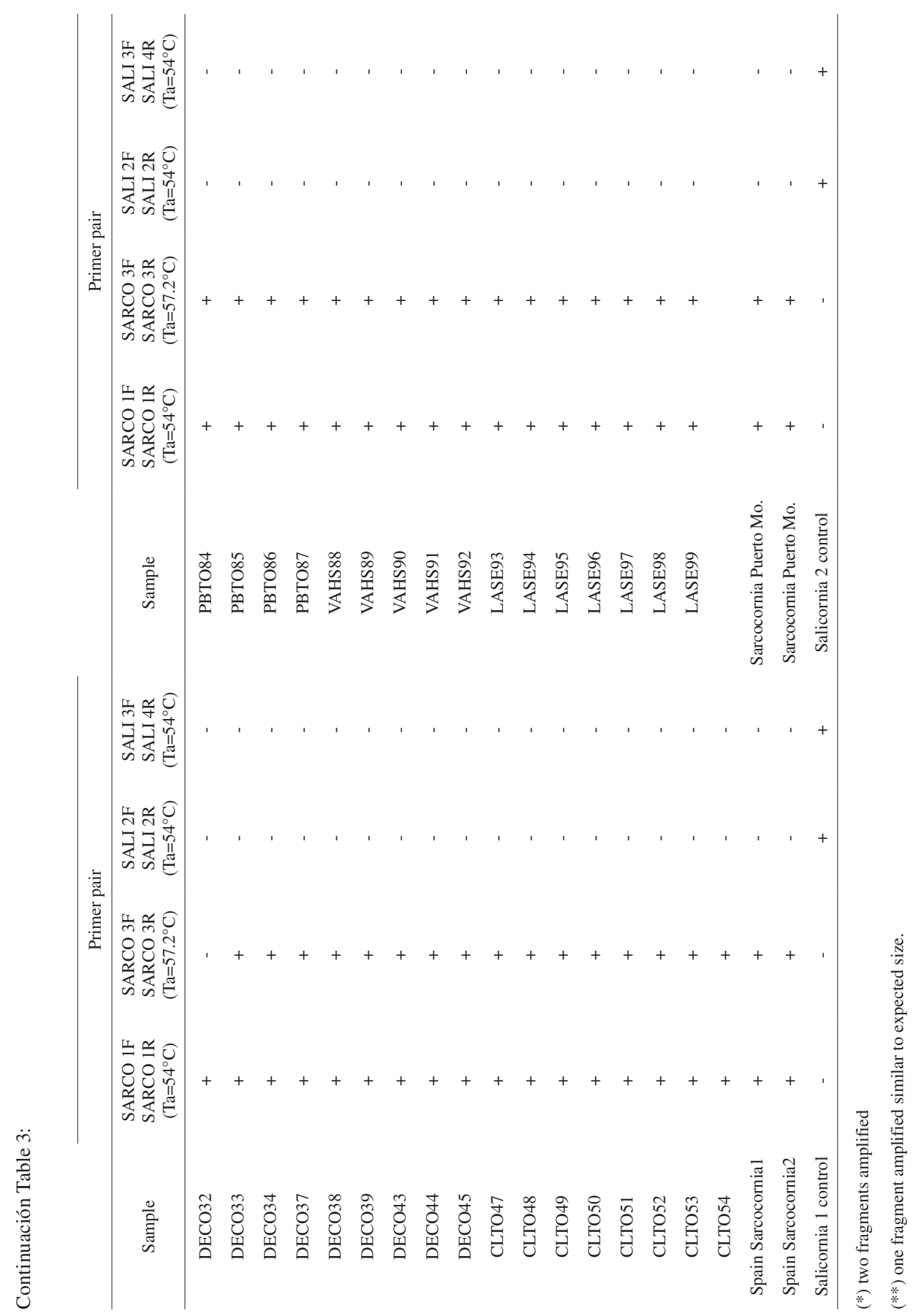




\section{Literature cited}

Acosta-Ruiz, M., J. Paniagua-Michel, J. Olmos-Soto, and E. Paredes-Escalona.

2011. Primer registro de la utilización de harinas de Salicornia bigelovii y Scomber japonicus en dietas prácticas para el cultivo super-intensivo de camarón Litopenaeus stylirostris. Latin American Journal of Aquatic Research, 39: 409-415.

Alonso, M.A. and M.B. Crespo.

2008. Taxonomic and nomenclatural notes on South American taxa of Sarcocornia (Chenopodiaceae). Annales Botanici Fennici, 45: 241-254. DOI:10.5735/085.045.0401

Davy, A.J., G.F. Bishop, H. Mossman, S. Redondo-Gómez, J.M.

Castillo, E.M. Castellanos, T. Luque, and M.E. Figueroa.

2006. Biological flora of the British Isles: Sarcocornia perennis (Miller). A.J. Scott. Journal of Ecology, 94: 1035-1048.

Doyle, J.J., and J.L. Doyle.

1987. Isolation of plant DNA from fresh tissue. Focus 12 (1): 13-15.

Faúndez, L., and J. Macaya.

1997. Presencia de Sarcocornia pulvinata (Fries) A. J. Scott (Chenopodiaceae) en Chile. Noticiario Mensual del Museo Nacional de Historia Natural Santiago, 328: 3-5.

Gunckel, H.

1978. Las especies chilenas del género Salicornia Linneo (Chenopodiaceae). Noticiario Mensual Museo Nacional de Historia Natural, Chile 22: 7-8.

Gutte, P., and G.K. Müller.

1985. Salzpflanzengesellschaften bei Cusco/Peru. Wiss. Z. Karl-Marx-Univ. Leipzig, Math. Naturwiss. Reihe, 34: 402-409.

Judd, W. S. and I.K. Ferguson.

1999. The genera of Chenopodiaceae in southeastern United States. Harvar Papers in Botany, 4: 365-416.

Kadereit, G., L. Mucina, and H. Freitag.

2006. Phylogeny of Salicornioideae (Chenopodiaceae): diversification, biogeography, and evolutionary trends in leaf and flower morphology. Taxon, 55: 617-642.

Kadereit, G., P. Ball, S. Beer, L. Mucina, D. Sokoloff, P. Teege,

A.E. Yaprak, and H. Freitag.

2007. A taxonomic nightmare comes true: phylogeny and biogeography of glassworts (Salicornia L., Chenopodiaceae). Taxon, 56: 1143-1170.

Katschnig, D., R. Broekman, and J. Rozema.

2013. Salt tolerance in the halophyte Salicornia dolichostahya Moss: Growth, morphology and physiology. Environmental and Experimental Botany, 92: 32-42.

Kwok, S., S.Y. Chang, J.J. Sninsky, and A. Wang.

1994. A guide to the design and use of mismatched and degenerate primers. PCR Methods Application Journal, 3: S39-S47.
Lu, D.H, M. Zhang, S.J. Wang, J.L. Cai, X. Zhou, and C.P. Zhu. 2010. Nutritional characterization and changes in quality of Salicornia bigelovii Torr. during storage. LWT - Food Science and Technology, 43: 519-524.

Montesinos-Tubée, D.

2012. Vegetación halófila de tres localidades andinas en la vertiente pacífica del sur de Perú. Chloris Chilensis: año $15 \mathrm{~N}^{\circ} 2$. Available: URL://http:www.chlorischile.cl Colsulted: 10/ago/2017

Nybom, H., K. Weising, and B. Rotter.

2014. DNA fingerprinting in botany: past, present, future. Investigative Genetics, 5: 1.

Philippi, R. A.

1895. Plantas nuevas Chilenas. Anales Universidad de Chile, sec. 1, 91: 415-432.

San Martín, C., M. Subiabre, and C. Ramírez.

2006. A floristic and vegetational study of a latitudinal gradient of salt marshes in South-Central Chile. Ciencias e Investigación Agraria, 33 (1): 33-40.

Scott, A.J.

1978. Reinstatement and revision of Salicorniaceae J. Agardh (Caryophyllales). Botanical Journal of the Linnean Society, 75: 357-374.

Soleimani, V.D., B.R. Baum, D.A. Johnson.

2003. Efficient validation of Single Nucleotide Polymorphisms in plants by allele-specific PCR with an example from barley. Plant Molecular Biology, 21: 281-288.

Steffen, S., P. Ball, L. Mucina, G. Kadereit.

2015. Phylogeny, biogeography and ecological diversification of Sarcocornia (Salicornioideae, Amaranthaceae). Annals of Botany, 115: 353-368.

Taberlet, P., E. Coissac, F. Pompanon, L. Gielly, C. Miquel, A.

Valentini, T. Vermat, G. Corthier, C. Brochmann, and E. Willerslev. 2006. Power and limitations of the chloroplast trnL (UAA) intron for plant DNA barcoding. Nucleic Acids Research, 35 (3): el 4. Ugozzoli, L., and R.B. Wallace.

1991. Allele-specific polymerase chain reaction. Methods Enzymol, 2: 42-48.

Ventura, Y., W.A. Wuddineh, M. Myrzabayeva, Z. Alikulov, I.

Khozin-Goldberg, M. Shpigel, T.M. Samocha, and M. Sagi.

2011. Effect of seawater concentration on the productivity and nutritional value of annual Salicornia and perennial Sarcocornia halophytes as leafy vegetable crops. Scientia Horticulturae, 128: 189-196.

Ventura, Y., and M. Sagi.

2013. Halophyte crop cultivation: the case for Salicornia and Sarcocornia. Environmental and Experimental Botany, 92: 144-153. 